\title{
CARRYING A WOLF, A GOAT, AND A CABBAGE ACROSS THE STREAM. METAMORPHOSES OF ATU 1579
}

\section{Piret Voolaid}

\begin{abstract}
The article discusses the functioning of the plot of a fixed tale type ATU 1579 (Carrying a Wolf, a Goat, and a Cabbage across the Stream) as a riddle and a narrative and its forms which have surrounded the plot and originate in traditional folklore genres. Folklore, reconstructed and placed in new contexts, emerges in new genres. In the present computer era, the plot has not only emerged in narrative and riddle genre, but has emerged in an entirely new context - it has been widely applied in the form of an interactive computer game. The different forms, contexts, functions and goals of the type plot may be regarded as aspects of the dynamic folklore process.
\end{abstract}

Key words: computer games, dynamic folklore process, Internet folklore, minor genres of folklore, narratives, riddles, the second life of folklore

Researchers studying folkloric material often face conflicts with the traditional categorisation. If a genre of folkore is difficult to define, and genre boundaries appear elusive the problem lies in the scholars' genre-oriented approach rather than units that elude defining (Ben-Amos 1982: 11). The archive-centred structure of the databases of the periphery of Estonian riddles ${ }^{1}$, which compilation began in 2001, follows the traditional linguistic approach, where folklore texts are categorised into types and folklore genres. But a folklore genre is not stable, and owing to various factors (such as, e.g., those governed by the context of usage or performance) narrative texts characteristically overlap in type and genre boundaries.

A performer of oral lore uses the structural patterns of traditional folklore genres unconsciously: a strict following of a specific genre and type is insignificant. What affects the performer most is the content motifs of lore, which is realised by a suitable folklore genre by means of the prescribed form. In reality, a folklore text may often draw upon different kinds of genres. While systematising folklore material, some scholars employ next to genre-specific rigid concepts (type and variant), content motifs and themes that may cross genre boundaries, thus pointing to the problems in defining genre boundaries (see, e.g., on the relationship of narrative and utterance Krikmann 2005: 91; on the relationship of riddle and joke Shmeleva \& Shmelev 2002: 97; topic instead of 
type and song instead of variant in the study of older and newer folk songs, see Ehin 2004: 10-11).

But how to handle a corpus of material collected over a long period of time and grouped according to the traditional and accepted genre-, type-, redactionand variant-specific archival system? According to this system, the contents and themes of the material can be discussed in the traditional framework - the genre categorisation. A scholar definitely should have a broader view rather than concentrate only on the static archive material.

This article discusses the plot registered under type number $1579^{2}$ in the tale type register (ATU), compiled by Antti Aarne and improved first by Stith Thompson and recently by Hans-Jörg Uther, in Estonian archival folklore material, and also forms emerged from other folklore genres that have surrounded the type.

In the ongoing computer era, which began to flourish ten or so years ago, an interesting metamorphosis of the tale type ATU 1579 has reintroduced it into a wider public focus in Estonia. On the one hand, it is about the transference of a motif from the past to the present, but on the other hand, a folkloric text constantly crosses the boundaries of folklore, maintaining contact with other forms of culture of its period. This orally transmitted text is now spreading in the Internet the same way it was once included in many Estonian children's books and school textbooks. The viability of this type is guaranteed by its ability to constantly adapt to the transforming context. Folklorists discuss the interrelation of cultural forms by means of terms folklore and the second life of folklore.

\section{PLOT ATU 1579 IN THE ESTONIAN TRADITION}

The entry of type 1579 in the ATU register reads as follows:

A man has to cross a stream in a boat that can hold himself and only one other object. He needs to transport a wolf (lion, jackal), a goat (sheep), and a cabbage (bundle of hay, pumpkin). He must be sure that when he is out in the boat the wolf does not eat the goat and the goat does not eat the cabbage.

There are two solutions: (1) He takes the goat across, then takes the wolf across and brings the goat back; he takes the cabbage across, comes back, and takes the goat across last. (2) He takes the goat over, then takes the cabbage over and brings the goat back; he takes the wolf over, and finally takes the goat over [H506.3]. 
The type is located in the second volume of the register entitled Tales of the Stupid Ogre, Anecdotes and Jokes, and Formula Tales, under the chapter of jokes and anecdotes Clever Man, type numbers 1525-1639. Although categorised among narratives, the character's task as if forms the narrative question of a riddle, providing two solutions in the pattern. The narrative form and the riddle-like question and answer form are both suitable for passing on this archaic plot of international spread. Also, the manuscripts of the Estonian Folklore Archives include recorded material from both folklore genres sharing the same plot. An example of the purely narrative form is the following tale from the collection of Matthias Johann Eisen.

Once a man wanted to cross the river in a skiff with a billy-goat, a dog (wolf) and a cabbage. The skiff carried only the man and one of the others. Had the man taken the goat across the river, it would have been a good start, but had the man gone back to bring the cabbages or the dog, the goat would have eaten the cabbages on the other bank, or the dog (wolf) would have killed the goat. The man didn't know what to do. Finally he came to an idea. Took the goat across the river, came back, took the dog across, but also brought the goat back to the cabbages. Took the cabbage to the skiff and left the goat on the riverbank. Took the cabbage to the dog - and the goat couldn't eat it - and now went after the goat. Finally took the goat across the river for the second time. Now all three were together on the bank, and the man did not let them eat or kill each other (E $54846<$ the 1920s. Place of collection unknown).

This text has been recorded from a single narrator and the dialogue form characteristic of riddles (one person asks the question and another one answers) is completely absent here.

Similarly, the files of Estonian riddles (which contain approx. 175,000 riddles) contain about 30 texts in question-answer form, with a plot pattern analogous to the plot of the previously discussed folk tale. The characters of this riddle type have to solve the puzzle presented in the question part of the plot, i.e. to cross a water obstacle (river, stream) in front of them and arrive at the opposite bank. The characters can use a craft (boat, raft, skiff, or trough), which unfortunately is not strong enough to carry all of them. The characters may tentatively be divided into subjects (who can operate the boat and are active characters) and objects (for whom the subjects are responsible, who are passive characters, and may pose a threat to each other). In the Estonian lore (either among riddles or narratives) the most popular variant of ATU 1579 is where the subject is a man (boatman, old man, boy, farmer, fisher, merchant) and the objects are a wolf (dog), goat (sheep, ram, billy-goat, hare) and a cab- 
bage head, thus forming a food chain. The water obstacle (river, stream) may be different, as could be the characters and the number of characters.

The earliest record of this type in the paper files of Estonian riddles originates in a book Lõbus rehkendaja. Ülesannete raamat. Laste arusaamise, mõtteteravuse ja isetegevuse edendamiseks. ['Merry Reckoner. Notebook. For developing understanding, insight and initiative in children'] published in 1918 by I. [= Joosep] Prümmel in Tallinn. An introduction to this book of 82 pages informs that the aim of the author, a journalist and teacher by profession (EAT: 244), like the aim of the authors of other similar works has been (e.g., Nugis 1939) to make dry arithmetics more interesting for children through entertaining tasks and puzzles. The book contains 214 tasks all in all requiring simple arithmetics and logical thinking. The fourth chapter entitled Finding a way out of a difficult situation, also includes the task of the plot of ATU 1579:

A farmer had to take a wolf, a billy-goat, and cabbages across the river in a boat. But the boat was so small that the man could only take the wolf with him, or the goat alone or the cabbages. The man was thinking:"If I take cabbages - and leave the wolf and the goat - the wolf will eat the goat. If I take the wolf across, the billy-goat will eat all the cabbages in the meantime." After long thinking a good idea came to him, and the man took all of them across the river. How did he do it?

First he took over the goat; the second time - he took over the wolf and brought the goat back. The third time he took over the cabbages, returned with an empty boat and the fourth time took the goat across (Prümmel [1918]: 36 and 76 (66)).

The same file page contains a very interesting footnote by Joosep Prümmel, compiler of the book.

This task has been known for more than a thousand years. Reportedly it was known already during the reign of Charles the Great (Charlemagne) (768-814). Compiler of the book (Prümmel [1918]: 36).

According to the ATU type register, the archaic international type was known all over the world, and circulated not only in Europe but, among other countries, also in Africa and the Arab world.

A similar task was later published in various Estonian children's magazines and journals, such as Ronk [Raven], no. 19, 20 (1924), Pioneer no. 12 (1957), children's newspaper Säde [Spark] no. 11 and 15 (1950) and no. 71(1965). In the 1965 issue no. 71 of Säde the traditional task characters - man, wolf and goat - were replaced by a family consisting of father, mother, son and daughter.

Solve this riddle! A family consisting of father, mother, son and daughter arrived at a river on their walk. They had to cross the river, but there was 
no bridge or pier to the other side. There was also no boatman to be seen. What to do? Finally, the father found in the bushes nearby a small boat, which must have been made for children. Once the father sat in the boat, it sank so deep in water that nobody else could step in it. Once the mother tried, the same happened. Only the two children could sit in the boat together. Mother said: "This little boat is of no use, we cannot get across the river together." But the father said: "If we are clever, we can all get to the other side on this boat. We can all row, can't we." The father was right. The entire family could cross the river on this tiny boat. How is this possible? Who went first? Who brought back the boat?

The answer to this riddle is not provided in the children's newspaper. The use of the ATU 1579 plot motif - crossing an analogous water obstacle - enables to regard the text a redaction of the same type.

The type's earliest archive document in riddle form originates in the 1922 collection by Walter Anderson. The material, written down by 14-year-old Loode Munna, a second grade pupil of the Tartu School for Girls, contains only the question part:

What is it? A fisherman had to take a wolf, a ram and a cabbage head across the stream. How did he do it? Had the fisherman taken the wolf first, the ram would have eaten the cabbage; how did he take them across, so that all three would get on the other side? If the skiff could carry only one at a time (A I 159 (18) < Tartu (1922)).

Even though the earliest record of this type comes from a printed source, the spread of the type cannot be considered a secondary tradition influenced by literature. The reason why this riddle has not arrived at the archives earlier may be the random collection. Munna's text does not appear to be connected with that by Prümmel (cf. the different names of characters), which is why it is difficult to claim anything specific about this. The total of 21 recordings of this riddle type have been contributed to the archives in the periods between 19221996; 14 recordings including the plot ATU 1579 arrived at the archives during the major campaign for collecting school lore in Estonia in 1992.

\section{TYPE ATU 1579 IN THE DIGITAL DATABASE OF ESTONIAN DROODLES}

Folklore motifs are often very flexible in adapting in time and transforming into newer forms of more recent origin. When visual riddles or droodles gained popularity among the Estonian schoolchildren in the 1980s, the riddle of the 
man, wolf, goat and cabbage discussed here was sometimes illustrated with pictures; the digital database of Estonian droodles (http://www.folklore.ee/ Droodles) also contains three illustrated records of this type (Voolaid 2003). This material is an elaboration of a textual tale/riddle type - namely, its adaptation into a riddle form of recent origin, a droodle. This is probably why the visual realisation of the ATU 1579 type has remained a unique intermediary form between a text riddle and a droodle. While the visual image of a droodle usually plays a decisive role in solving the riddle, in this case it makes no difference whether the image of the river, boat, man, wolf, goat and cabbage head is drawn or not: the riddle can be solved after careful listening to the question part of the riddle (tale). Yet the riddle has prompted visual representation.

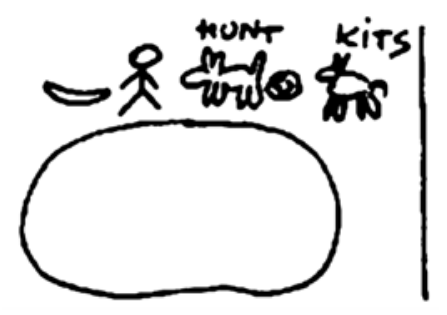

$$
\begin{aligned}
& \text { hunt - wolf } \\
& \text { kits - goat }
\end{aligned}
$$

How can a man take a wolf, a goat and a cabbage over the lake? What does the man have to do? At first the man takes a goat over the lake by boat, because the wolf doesn't eat cabbage. The man returns by boat and next takes the cabbage over. Coming back, he brings the goat back again. Then gets the wolf and takes it over the lake. The cabbage and the wolf have been taken on the other side of the lake. Now the man goes and brings the goat, too, over the lake (RKM, KP 19, 278 (5) < anon (1992)).

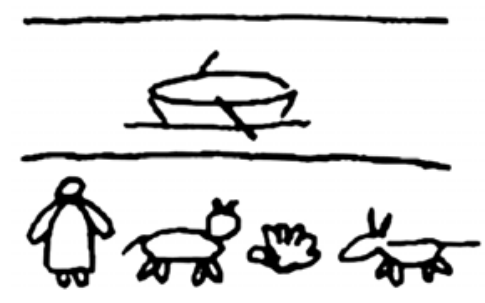

A gaffer needs to take a ram, a cabbage and a wolf over the river. How can he get them over the river if the boat carries only one at a time. First he takes the ram over, then takes the wolf and brings the ram back, then he takes the cabbage and then returns again for the ram (RKM II 347, 222/3 (28) < Mall Hiiemäe (1980)). 


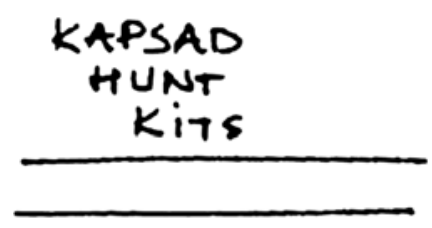

kapsad - cabbage

hunt - wolf

kits - goat

How can a man take everything over the lake so that they wouldn't eat each other? There is only room for one at a time. First he takes the goat over, then the wolf, brings the goat back. Takes the cabbages over and then the goat (RKM, KP 36, 111 (16) < Nele Rägo (1992)).

Illustrated variants of the riddle, where its listeners cannot draw on general background knowledge but are required a knowledge of the performance, a deduction and a keen mind, have also been collected in Finland (Kaivola-Bregenhøj 2001: 70). Ulla Lipponen has compiled a collection, based on school lore collected in 1986, entitled Kilon poliisi ja muita koululaisvitsejä, which includes type ATU 1579 (Lipponen 1988: 39). The text recorded in Kuopio is illustrated accordingly.

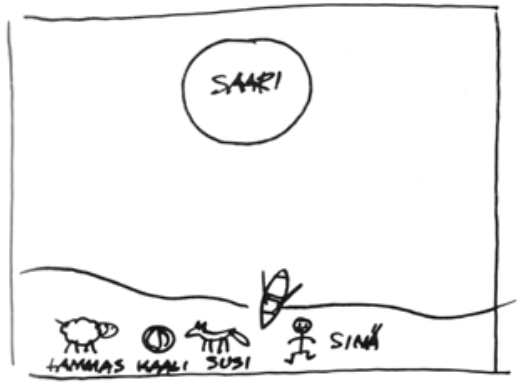

saari - island
lammas - sheep
kaali-cabbage
susi - wolf
sinä - you

You've got to get a CABBAGE, a WOLF and a SHEEP across to an island in a rowing boat so that the wolf cannot eat the sheep nor the sheep the cabbage. How do you do it? - First you take the sheep to the island. Then you fetch the wolf and leave it on the island, taking the sheep back to the shore. Leave the sheep on the shore and take the cabbage across and leave it with the wolf. Then you return for the sheep and row it across to the island.

As an example of adaptation, the text displays regional idiosyncrasies: in Finland, the Land of Thousand Lakes, a lake with an island is preferred, while in the Estonian redaction the riddle is about crossing a river.

Both narrative form and the riddle-like question/answer form, sometimes illustrated by a visual image, are suitable for representing the plot. We may 
only speculate whether in riddle form it is "the second life" (cf. Honko 1998: 77) of the narrative text as another folklore genre; however, at least now the logic puzzle seems to prevail. In the Finnish text discussed before, for example, no attention is drawn in the question to the fact that the boat carries only two characters at a time; evidently, this is already an immanent knowledge in the tradition. But crossing a water obstacle can be solved again and again.

\section{TYPE ATU 1579 IN THE INTERNET ERA - DYNAMIC FOLKLORE PROCESS}

\section{Archiving}

In terms of archive technology, the recorded texts of type ATU 1579 have been collected over the past century from the Estonian manuscript collections and various publications into paper files, which have been digitised by modern technological means (computers). The computer era and compilation of textual databases have introduced new problems - for example, the manuscript texts should be incorporated in extensive databases as digital texts. Over the past decade, the WWW environment has become an inexhaustible source of materials for scholars of the humanities - folklorists, linguists, psychologists, sociologists, etc. An abundance of new folklore characteristic of a specific period and culture has emerged in the Internet; the advantage of this material compared to the folklore material held in the archives is coherence of the process. A scholar working with archive sources works with static material, isolated from the context of usage, whereas the Internet as a communication medium enables to study the society, which means the observation of the process (Runnel 1999: 19). While the Estonian archives contain approximately 30 texts with the ATU 1579 plot (compared to the total number of collected riddles, which is 175,000 , this type is not very widely spread, though sometimes the number of archive entries reflects only the collection of folklore rather than its actual spread), the plot has enjoyed interesting developments in the folkloric sense and wide spread in the computer era. Archaic folkloric motifs may assume different forms in the Internet environment, and so has the pattern of the ATU 1579 plot become the source of inspiration for creators of computer games; these games have become widely popular among online players. This abounding computer game material, however, is not represented in any digital database of Estonian folklore. So far, computer games cannot be "fixed" or entered into a database, but the problem exists and will probably come to a solution in the future. 


\section{Folklore and the second life of folklore in the context of ATU 1579}

Linda Dégh, one of the leading folklore scholars of the twentieth century, has demonstrated that today's electronic media contribute to the creation and maintenance of folklore (1994). L. Dégh has pointed out that common cultural properties and ways of thinking manifest in folktales can be observed in television and mass circulation publications. In modern times it is taken for granted that folklore is not an artifact but a dynamic historical process. Different scholars have used different terminology while observing the dynamic processes of folklore.

According to Finnish folklorist Lauri Honko (1998: 78), the plot of type ATU 1579 can be also regarded as an example of the second life of folklore, as over the times it has adjusted its form and function according to the environment, manifesting qualities characteristic of the second life of folklore while being fixed in new layers and undergoing changes in function. This justifies a question - in which aspect can the large-scale interactive application of the ATU 1579 plot be considered a part of folklore, and in which aspect can it be considered a part of the second life of folklore? Even though it is hard to draw a line between folklore and the second life of folklore, this "by-product" of folklore enables to observe the dynamics of the type under discussion. The plot, where characters on one side of a water obstacle need to cross the water obstacle under predetermined circumstances is clearly the same than in the narrative from the collection of Matthias Johann Eisen discussed before, as well as the textual riddles and droodles in question/answer form recorded at the beginning of the 20th century, as well as the modern interactive computer game.

While the assumed primary function of ATU 1579 is a question/answer dialogue, during which the respondent (unless s/he has heard the question beforehand) needs to sharpen his logic and come up with an effective strategy for solving the task, the computer environment adds another function to this archaic type. For a plot to be turned into a computer game, the programmer of the game first has to technically solve the task. As a puzzle of logic, the plot is an excellent educational material for students of information technology. Michael Huth, professor at the Imperial College London, for example, has included the programming of the plot ATU 1579 into a computer game among the study materials of his course Logical Foundations of Programming (Huth 2005, accessed in October 15, 2005). By using SMV modelling, a program is created to solve this task. In such cases the solution of the question presented in the text of the task is no longer relevant; the important thing here is pre- 
senting the solution in an interactive form for a player. In the new context of use, the contents of the riddle have transformed into a tool for learning a mathematical language, and hence we can talk about the second life of folklore.

Now, can the process of playing the game be considered an actual second life of folklore? Is it possible to identify folkloric aspects of a computer game? The alternating relationship between folklore and the second life of folklore is very generally represented in the following table.

Table 1. The ATU 1579 plot in three different stages of usage representing the dynamics of the folklorisation process

\begin{tabular}{|c|c|c|}
\hline Traditional folklore & $\begin{array}{l}\text { New functions in the } \\
\text { computer era - the } \\
\text { second life of folklore }\end{array}$ & $\begin{array}{l}\text { Folklore in the new } \\
\text { cultural context }\end{array}$ \\
\hline $\begin{array}{l}\text { The plot of ATU } 1579 \\
\text { in traditional folkloric } \\
\text { context (in the pre- } \\
\text { computer period). The } \\
\text { plot is passed on from } \\
\text { generation to generation } \\
\text { as a piece of traditional } \\
\text { folklore in narrative } \\
\text { form, or as a riddle in } \\
\text { question/answer form. } \\
\text { In narrative form, the } \\
\text { question in the text has } \\
\text { to be answered. }\end{array}$ & $\begin{array}{l}\text { The plot of ATU } 1579 \text { is } \\
\text { used as an educational } \\
\text { tool for students of } \\
\text { information technology. } \\
\text { The folkloric text forms } \\
\text { a basis where the } \\
\text { solution to the question } \\
\text { is already known. The } \\
\text { function of the text in } \\
\text { question/answer form } \\
\text { has changed: a } \\
\text { programmer's task is to } \\
\text { transpose it into a } \\
\text { visually attractive } \\
\text { computer game by using } \\
\text { technological means. }\end{array}$ & $\begin{array}{l}\text { The plot of ATU } 1579 \\
\text { has re-entered the new } \\
\text { context. The spread of } \\
\text { the visual interactive } \\
\text { game is physically } \\
\text { limited to the computer. } \\
\text { At least two folkloric } \\
\text { domains emerge: (1) the } \\
\text { domain of players as a } \\
\text { new lore group, and } \\
\text { (2) the user may spread } \\
\text { the plot as traditional } \\
\text { oral/written folklore. } \\
\text { Once again, finding a } \\
\text { correct solution to the } \\
\text { question becomes } \\
\text { important. }\end{array}$ \\
\hline
\end{tabular}

\section{Observation of the development of ATU 1579 as a computer game}

Since 2003 a plethora of online games have become available for the Estonian players at the website Mängukoobas (http://mangukoobas.lahendus.ee, see Fig. 1), or Game Cave in English, where a player can choose between action and adventure games, puzzles and strategy games, board and casino games, 
sports games, multiplayer games and games based on films. The site is very popular among the younger generation of Estonians: in October 2003 the first users discovered the webpage, and by Christmas the same year the site had 8,000 and by June 2004 the number of registered users was 37,000 (Sarv 2004: 16). The age of the majority of the users ranges from five to sixteen. The game portal was created for entertainment, to meet the personal needs of the creators (Sarv 2004: 16). Registered users have called themselves Cave Monsters, whose count is seen at the home page. At any moment of time, the number of players can be followed in real time. Users can add new games to the portal, and a forum for chatting and posting comments is opened for each game.

In July 2004, a user of the portal (with username Zakuzaku) posted the game Wolf, Sheep and Cabbages. The game under code 48601 in the category of puzzles and strategy games is characterised as follows:

The good old puzzle game is now available on your computer... you have to get the wolf, the sheep and cabbages across the river in a boat (http:// mangukoobas.lahendus.ee/index.php?0035486015).

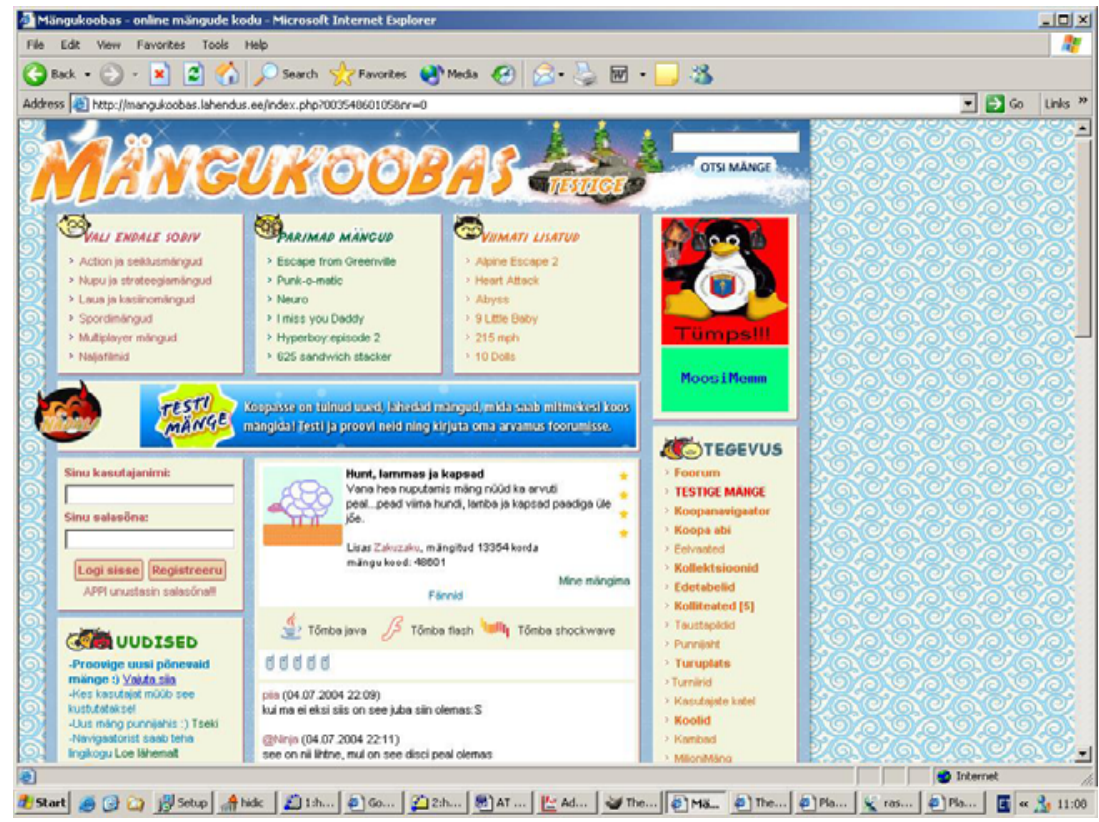

Figure 1. Popular game website Mängukoobas, or Game Cave (Mängukoobas 2005), displaying a link to the game Wolf, Sheep and Cabbages (ATU 1579). 
The link on the website opens the site Plastelina Logic Games (Figure 2a), which is not located in an Estonian domain (the portal is in English, German, Spanish and Portuguese), but the plot ATU 1579 is available for the Estonian children in the form of a Flash Shockwave ${ }^{3}$ and JavaScript ${ }^{4}$ game. Mängukoobas portal also counts the number a game has been played: by June 15, 2005 this particular game had been played for 15,000 times. Certainly, the number does not indicate the precise number of users, as the number of times that a player can play a game is not limited. Wolf, Sheep and Cabbages is, in fact, the easiest level of the game: a player who completes it can move on to the next level (Fig. 2b), where the player's task is to take three cannibals and three missionaries across the river, whereas attention has to be paid to the fact that if the number of cannibals on one riverbank exceeds the number of missionaries, the cannibals will devour the latter. Having completed the ATU 1579 version of missionaries and cannibals, the player can test his/her skills at more advanced levels.

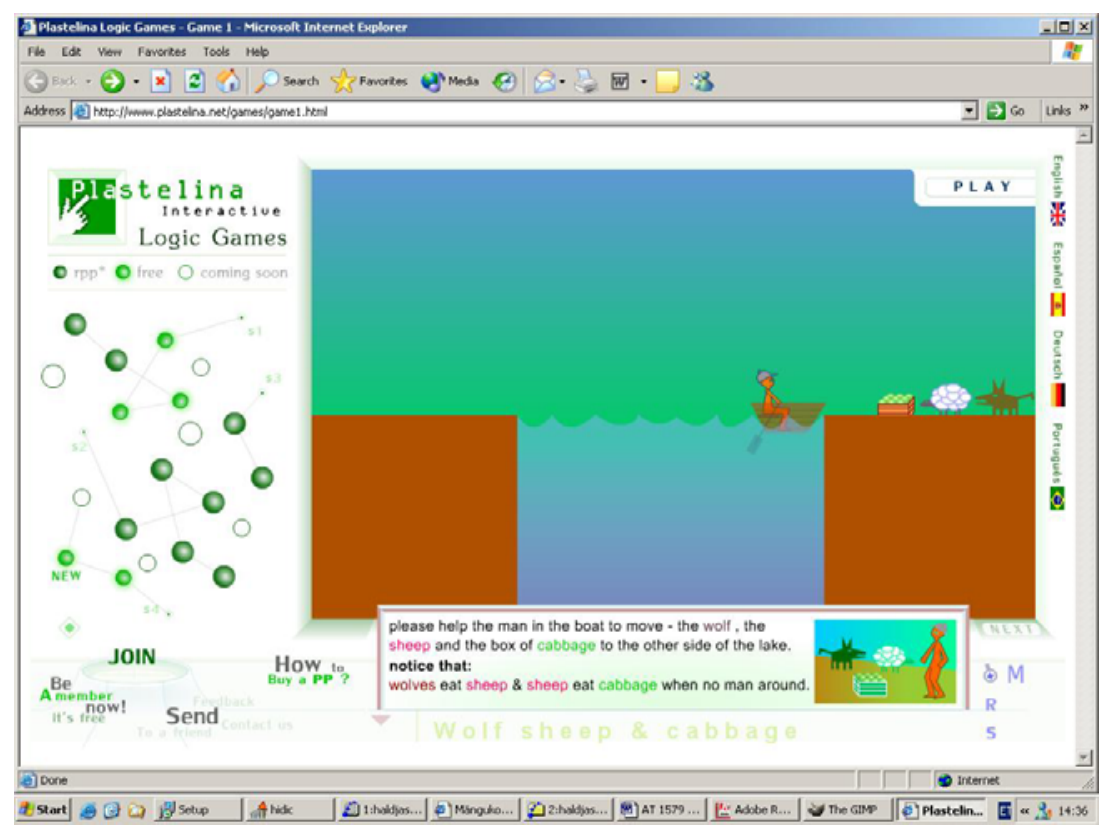

Figure 2a. Link from Mängukoobas to the English-language game, available at http:// www.plastelina.net/games/game1.html (Plastelina 2005). 


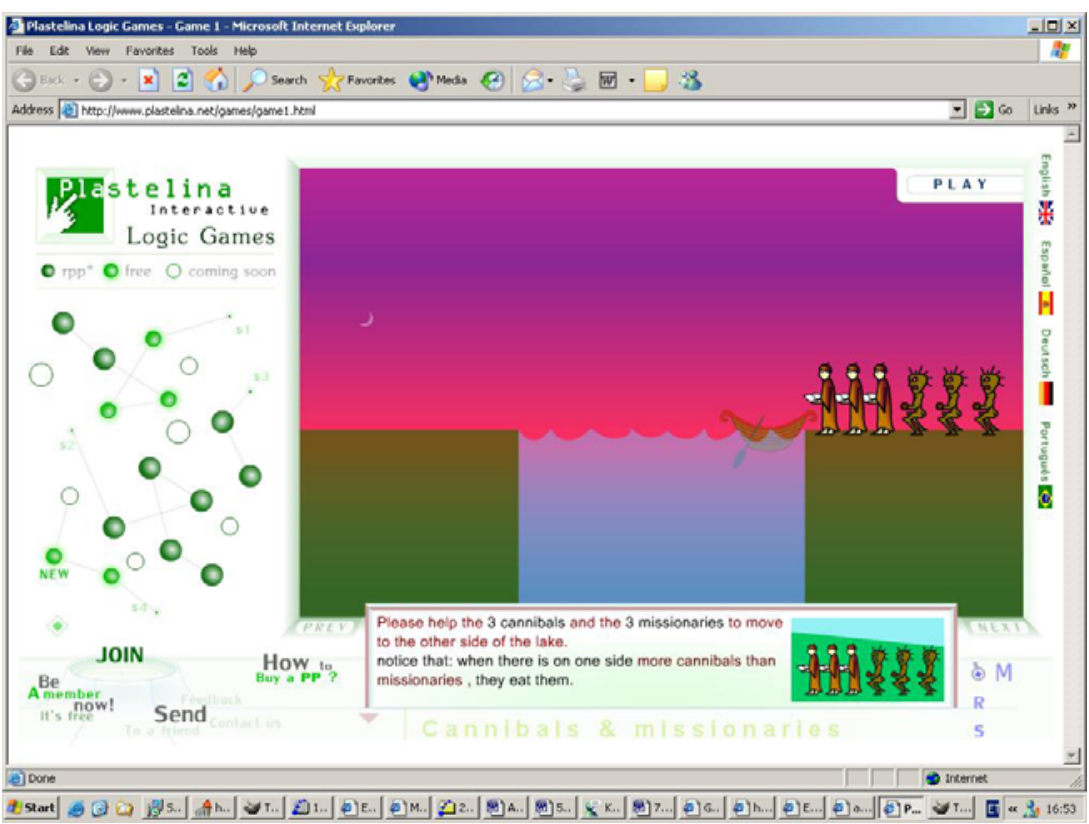

Figure 2b. Link from Mängukoobas to the advanced level of the Wolf, Sheep and Cabbage game, where the player has to get three cannibals and three missionaries across the river (Plastelina 2005).

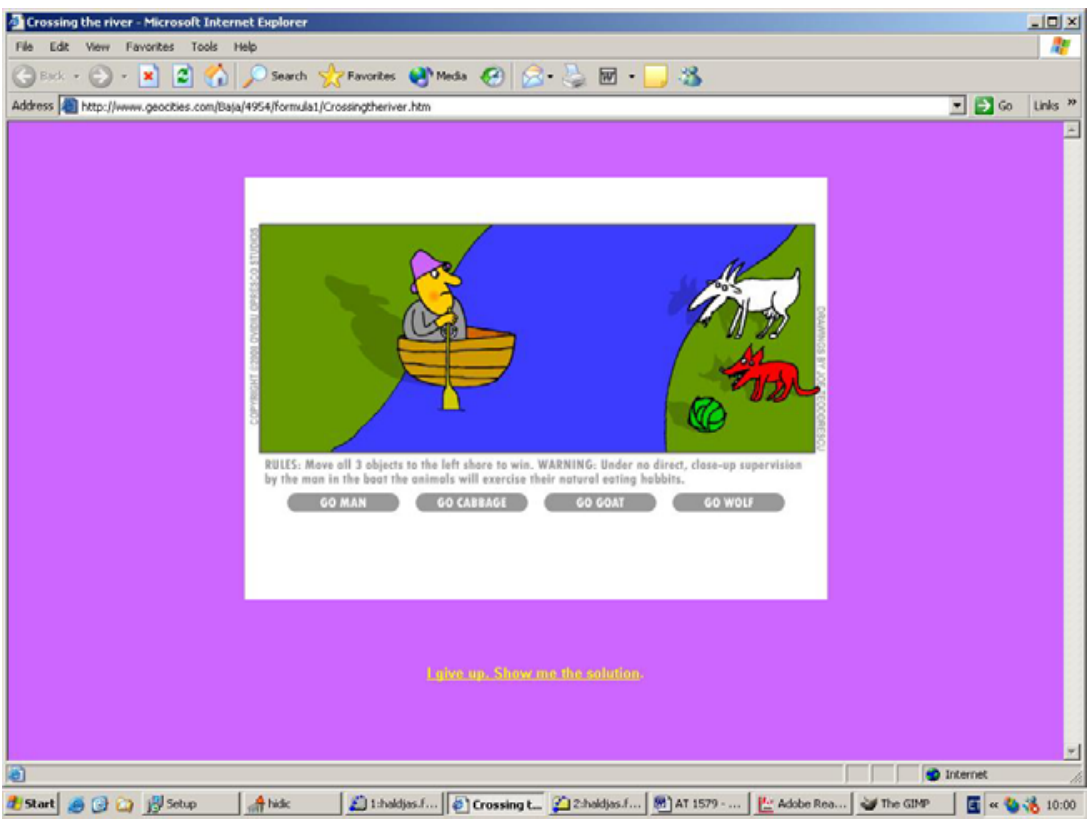

Figure 3. Animated interactive version of the riddle ATU 1579, available at http:// www.geocities.com / Baja / 4954 / formula1 / Crossingtheriver.htm (Crossingtheriver 2005). 


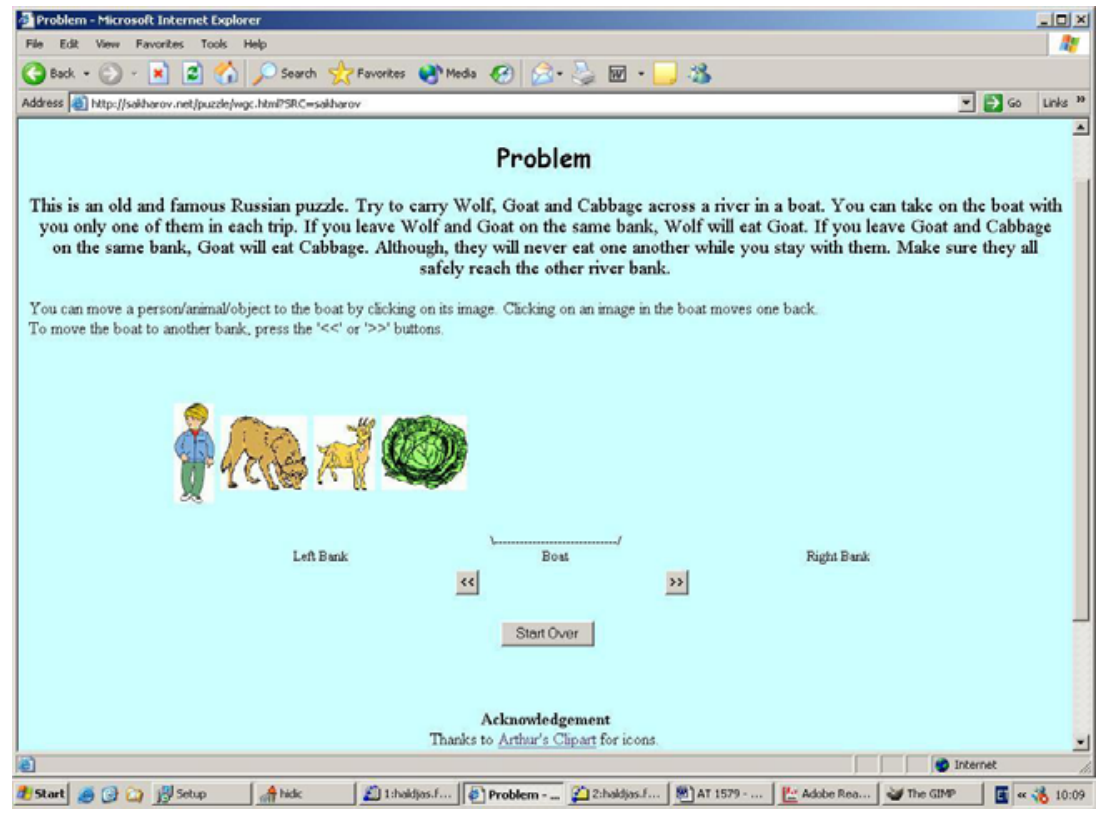

Figure 4. Animated interactive version of the riddle ATU 1579, available at http:// sakharov.net/puzzle/wgc.html? SRC=sakharov (Sakharov 2005).

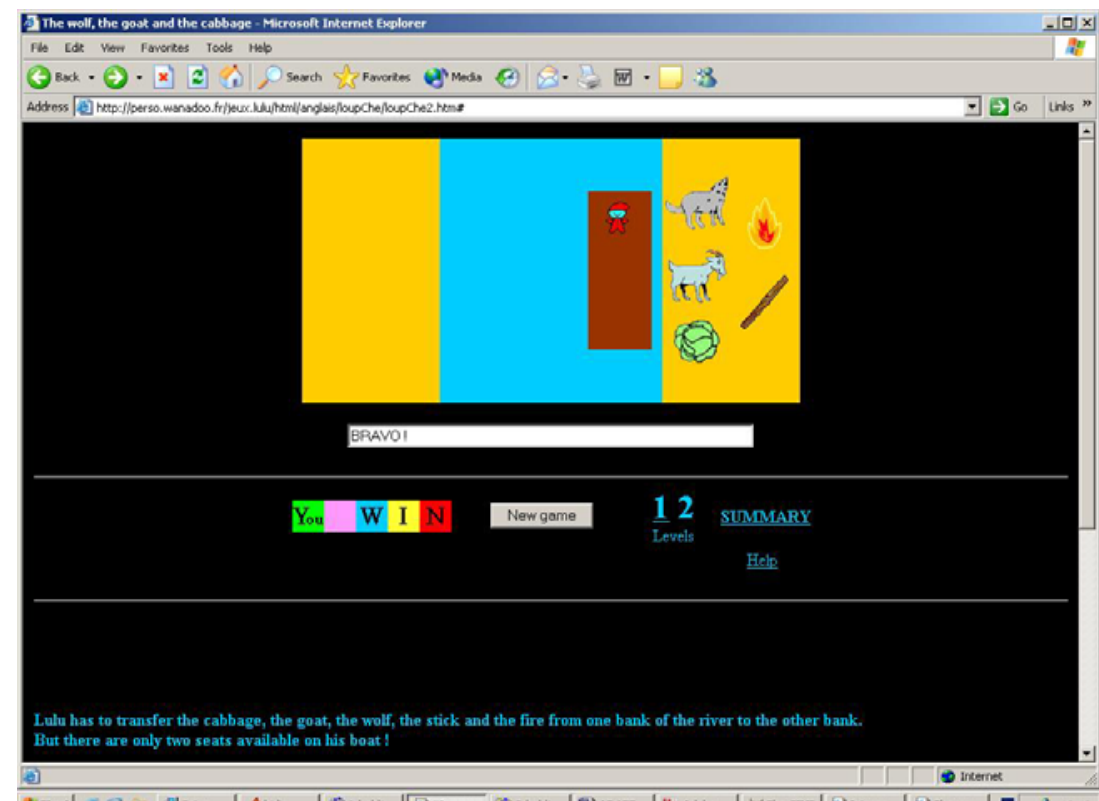

Figure 5. Animated interactive version of the riddle ATU 1579 with a larger number of characters, available at http://perso.wanadoo.fr/jeux.lulu/html/anglais/loupChe/ loupChe2.htm\# (Lulu Games 2005). 
An identical game has become available for online players in another popular portal of entertainment targeted to the younger generation at website games.kuuluta.com/onlinefoorum.php?mis=1006\&mislk=2 (games.kuuluta.com 2005). Registered visitors of this site are called Tigers, and like in the previous portal, the registered users can comment on the games.

The number of analogous animated interactive online computer games is truly remarkable (see, e.g., Fig. 3-5).

Modern computer era has also generated an IQ test game in Shockwave Flash (see Fig. 6a-6c). This game is reportedly used in Japan at job interviews. I first received information about the game in February 2005 through a mailing list (the list has 25 members), which is generally a typical way of spreading Internet folklore. ${ }^{5}$ Letter Fwd: Fw: some puzzling :o) included a brief task in the Estonian language and the web address:

This is an IQ test given to job applicants in Japan: Everybody has to cross the river.

To start the game click on the blue circle on the right. To move the raft click on the red poles on the river. To move the people on the raft or back on the bank click on them.

Rules: Only two persons on the raft at a time. The father can not stay with any of the daughters without their mother's presence. The mother can not stay with any of the sons without their father's presence. The thief (with striped shirt) can not stay with any family member if the policeman is not there. Only the father, the mother and the policeman know how to operate the raft. http: / / www.sandstorming.com/dump/other / riverIQGame.swf If you cannot solve it otherwise, take a paper and a pen and start practising! (From personal materials of Piret Voolaid).

The instructions of the game have most likely been translated from the English language. Entering the .swf file of the game with the title riverIQGame in different search engines opens a large number of websites (A Google search on October 15, 2005 yielded 147 results). An intriguing (and at least in the Estonian context, a folkloric) comment about the use of this riddle at job interviews in Japan, makes us wonder if this is really true; however, the actual existence of this IQ test in the Japanese cultural context deserves a separate study.

I came across the English-language version of the game rules in an interactive forum: These rules are a literal translation of the meaning of the Estonian letter, and in addition included results depending of the time spent on the puzzle: 
Result:

if you succeed in

4 minutes: you are a genius.

6 minutes: You are exceptionally intelligent.

10 minutes: You are very intelligent.

20 minutes: You are average.

25 minutes: You are a bit slow.

30 minutes or more: You are a dumbarse.

(http://forums.emulator-zone.com/archive/index.php/t-259.html, accessed on October 15, 2005 - Emulator Zone Forum 2005.)

The application of infotechnological solutions has resulted in a modern logic puzzle in riddle form. In this puzzle there are more characters than in the already known variant of the man, wolf, goat and cabbage - here the player must get a mother with two daughters, a father with two sons, a policeman and a robber across the river. Being transmitted in virtual space from one computer user to another, overcoming language barriers by means of the visual image, this puzzle is definitely a part of contemporary interactive Internet folklore.

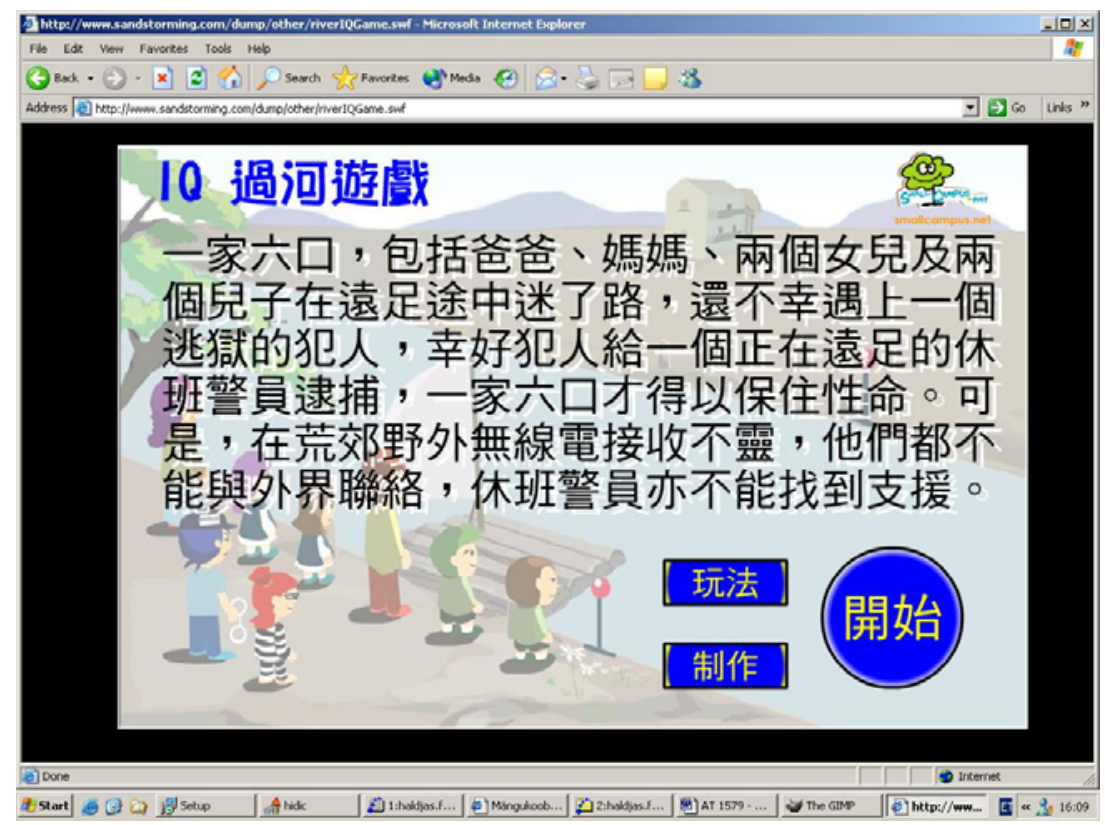

Figure 6a. The Japanese IQ Test on the motifs of ATU 1579 (http://dagobah.biz/flash/ riverIQGame.swf, accessed on April 5, 2005 - River IQ Game 2005). To start the game click on the (blue) circle on the right. 


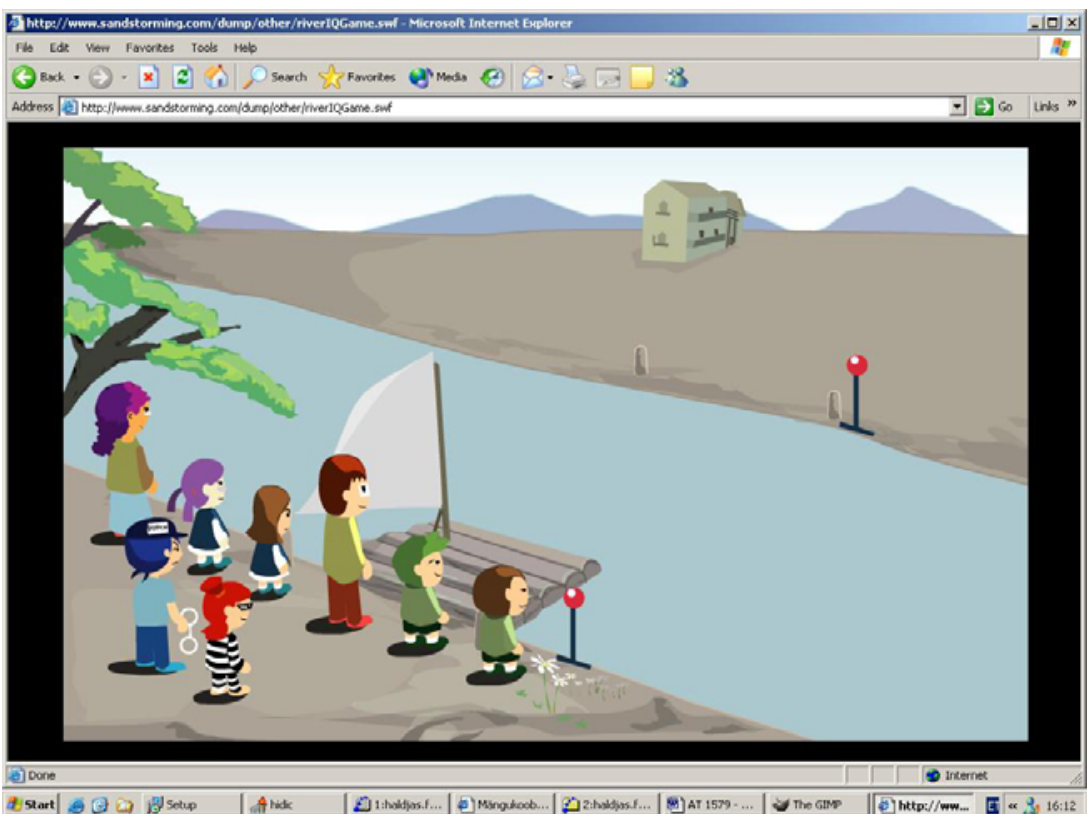

Figure 6b. The Japanese IQ Test. Take the mother with two daughters, the father with two sons, the policeman and the robber across the lake on the raft.

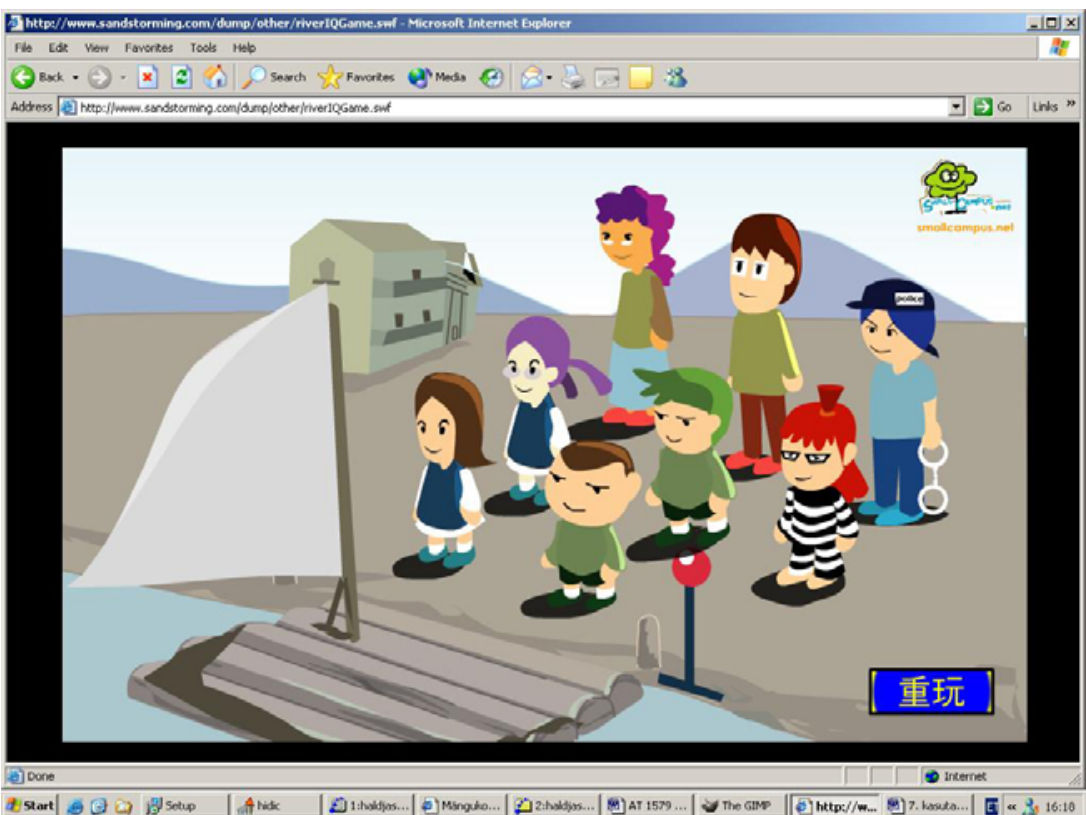

Figure 6c. The Japanese IQ Test is successfully completed. Everybody is safely on the other side of the river. 


\section{CONCLUSION}

It may thus be concluded that type 1579 of the Aarne-Thompson-Uther tale type register, entitled Taking the Wolf, the Goat and the Cabbage Across the River, may occur in both narrative form and in question/answer riddle form. Particularly the latter in the form of a logic puzzle seems to have constituted the core of this plot over the times. During the modern computer era, the new form of a computer strategy game, where an interactive dialogue is established between a programmed computer (performer of the riddle) and the player (solver of the riddle), has been added to the traditional folk tale and riddle genre. The same folkloric plot has merged into new cultural layers, new forms and has assumed additional functions.

Computers and the Internet are thus an extremely powerful medium for distributing the plot and establishing it in the tradition. A quote by Sergei Nekliudov supports this view:

One does not have to be particularly insightful to predict that the next change in the paradigms of folklore will be (or already have been) triggered by computer technology and the Internet, though it is virtually impossible to predict the development dynamics of these quasi-folkloric new forms (Nekljudov 2003: 26).

\section{COMMENTS}

1 Peripheral subcategories of riddles have been grouped in online databases Estonian Droodles (http://www.folklore.ee/Droodles (2003)), Eesti (liit)sõnamängud [Estonian (Compound) Puns] (http://www.folklore.ee/Sonamang (2003)), Eesti keerdküsimused [Estonian Conundrums] (http://www.folklore.ee/Keerdkys (2004)), Eesti lühendmõistatused [Estonian Acronyms] (http://www.folklore.ee/Lyhendid (2004)).

2 The type is registered under the same type number also in the earlier Aarne-Thompson tale type register $(\mathrm{AT})$.

${ }^{3}$ A vector-graphic animation technology developed by Macromedia Inc, requires little scroll extent and is independent of the browser. If different browsers are equipped with necessary plug-ins, the Flash-animations are displayed identically.

${ }^{4}$ A scripting language developed by Netscape to enable Web authors to design interactive sites.

${ }^{5}$ At the beginning of the article it was claimed that the total number of texts contributed to the Estonian Folklore Archives represents the collection rather than the type's actual spread. If the plot of type ATU 1579 is forwarded to 25 members of the list, then in terms of collection this would stand for 25 archive entries. 


\section{MANUSCRIPT SOURCES}

The manuscript files of the Estonian Folklore Archives at the Estonian Literary Museum:

A = Collection of Nursery Songs of Walter Anderson (1921-1939)

$\mathrm{E}=$ Folklore collection of Matthias Johann Eisen (1880-1934)

RKM $=$ Folklore collection of the Department of Folkloristics at the Estonian Literary Museum (1945-1994)

RKM, KP = Collection of school lore of the Department of Folkloristics at the Estonian Literary Museum (1992)

Personal materials of Piret Voolaid - in possession of the author.

\section{REFERENCES}

AT = Aarne, Antti \& Thompson, Stith 1964. The Types of the Folktale: A Classification and Bibliography. Folklore Fellows' Communication, 184. Helsinki: Suomalainen Tiedeakatemia.

ATU = Uther, Hans-Jörg 2004. The Types of International Folktales: A Classification and Bibliography: Based on the System of Antti Aarne and Stith Thompson, 2: Tales of the Stupid Ogre, Anecdotes and Jokes, and Formula Tales. Folklore Fellows' Communications, 285. Helsinki: Suomalainen Tiedeakatemia.

Ben-Amos, Dan 1982. Perinnelajikäsitteet. In: Järvinen, Irma-Riita \& Knuutila, Seppo (eds.). Kertomusperinne: Kirjoituksia proosaperintun lajeistta ja tutkimuksesta. Tietolipas, 90. Helsinki: Suomalaisen Kirjallisuuden Seura, pp. 11-28. In English: The Concepts of Genre in Folklore, Studia Fennica, Review of Finnish Linguistics and Ethnology, 20 (1976), pp. 30-43. [Issue of Folk Narrative Research, Some Papers Presented at the VI Congress of the International Society for Folk Narrative Research.]

Crossingtheriver 2005. Available at http://www.geocities.com/Baja/4954/formula1/ Crossingtheriver.htm, last accessed on October 15, 2005.

Dégh, Linda 1994. American Folklore and the Mass Media. Folklore today. Bloomington \& Indianapolis: Indiana University Press.

EAT $=$ Kleis, Richard (ed.) 1932. Eesti avalikud tegelased: Eluloolisi andmeid . [Public figures in Estonia: Biographies] Tartu: Eesti Kirjanduse Selts.

Ehin, Kristiina 2004. Eesti vanema ja uuema rahvalaulu tõlgendusvõimalusi naisuurimuslikust aspektist. [Interpretations of Estonian archaic runo songs and newer end-rhyme folk song from the perspective of women's studies.] MA thesis. Tartu: The Estonian and Comparative Folklore Department of the University of Tartu. Available also at http://www.utlib.ee/ekollekt/diss/mag/2004/b16708660/Ehin.pdf, last accessed on October 15, 2006.

Emulator Zone Forum 2005. Available at http://forums.emulator-zone.com/archive/ index.php/t-259.html, last accessed on October 15, 2005.

games.kuuluta.com 2005. Available at http://games.kuuluta.com/onlinefoorum.php? mis $=1006 \&$ mislk, accessed on October 15, 2005. [Link currently inactive.]

Honko, Lauri 1998. Folklooriprotsess. Mäetagused: Hüperajakiri, 6, pp. 56-84; see also http://www.folklore.ee/tagused/nr6/honko.htm, last accessed on October 15, 2005. In English: The Folklore Process. Folklore Fellows' Summer School Programme. Turku: FFSS. 
Huth, Michael 2005. CIS 301. Logical Foundations of Programming, Spring 2000. Available at http://www.cis.ksu.edu/ huth/301/puzzle.html, last accessed on October $15,2005$.

Kaivola-Bregenhøj, Annikki 2001. Riddles: Perspectives on the Use, Function and Change in a Folklore Genre. Studia Fennica: Folkloristica, 10. Helsinki: Finnish Literature Society.

Krikmann, Arvo 2005. Ütlusfolkloor. [Lore of sayings] Metsvahi, Merili \& Valk, Ülo (eds.). Regivärsist netinaljadeni: Sissejuhatus rahvaluulesse. [From Kalevala-metric folk verse to Internet jokes] Tallinn: Koolibri, pp. 91-99.

Lipponen, Ulla 1988. Kilon poliisi ja muita koululaisjuttuja. [Kilon poliisi and other school narratives] Helsinki: Suomalaisen Kirjallisuuden Seura.

Lulu Games 2005. Available at http://perso.wanadoo.fr/jeux.lulu/html/anglais/ loupChe/loupChe1.htm, last accessed on October 15, 2005.

Mängukoobas 2005. Available at http://mangukoobas.lahendus.ee/ index.php?00354860105\&nr=0, last accessed on October 15, 2005. [Link currently inactive.]

Nekliudov, Sergei 2003. Vene rahvaluuleteadus ja strukturaalsemiootilised uurimused. [Russian folkloristics and structural-semiotic studies] Jaago, Tiiu (ed.). Pärimus ja tõlgendus: Artikleid folkloristika ja etnoloogia teooria, meetodite ning uurimispraktika alalt. [Lore and Interpretation. Articles on Theory, Methods and Research Practices of Folkloristics and Ethnology] Tartu: Tartu Ülikooli Kirjastus, pp. 26-36.

Nugis, Elmar 1939. Ajaviite-taskuraamat: Katsed, kunsttükid, mängud, mõistatused, mitmesugust. [Pocketbook of fun: Tests, tricks, games, varia] Tallinn: [s.n.].

Pioneer: [Children's magazine] 1957, No. 12.

Plastelina 2005. Available at http://www.plastelina.net/games/game1.html, last accessed on October 15, 2005. [Link currently inactive.]

Prümmel, I. [= Joosep] [1918]. Lõbus rehkendaja: Ülesannete raamat: Laste arusaamise, mõtteteravuse ja isetegevuse edendamiseks. [Merry reckoner: Notebook: For developing understanding, insight and initiative in children] Tallinn: Rahvaülikool.

River IQ Game 2005. Available at http://dagobah.biz/flash/riverIQGame.swf accessed on October 15, 2005. [Link currently inactive.]

Ronk: [Children's magazine] 1924, No. $19 \& 20$.

Runnel, Pille 1999. Välitööde võimalikkusest internetis. [Perspectives of fieldwork in the Web] In Kalmre, Eda (ed.). Kuuldust-nähtust. Tänapäeva folkloorist 4. [Contemporary Folklore 4.] Tartu: Eesti Kirjandusmuuseum, pp. 13-30.

Sakharov 2005. Problem. Available at http://sakharov.net/puzzle/wgc.html?SRC= sakharov, last accessed on October 15, 2005.

Sarv, Mari 2004. Mängukoobas aitab vihmast päeva veeta. [Games portal saves a rainy day] Eesti Päevaleht, June 17, pp. 16, see also http://www.epl.ee/?artikkel=267896, last accessed on October 15, 2005.

Säde: [Children's newspaper] 1950, No $11 \& 15 ; 1965$, No 71.

Shmeleva, Elena \& Shmelev, Aleksei 2002. Russkii anekdot: Tekst i rechevoi zhanr. [Russian jokes: Text and oral genre.] Studia philologica: Series minor. Moscow: Yazyki slavianskoi kultury.

Voolaid, Piret 2003. Estonian Droodles. Available at http://www.folklore.ee/Droodles. Tartu: Estonian Literary Museum. 